\title{
Comparable sample texts of Surgut Khanty in 1996 and 2008'
}

\section{Introduction}

The aim of this paper is to introduce six sample texts of Surgut Khanty. These texts represent two variations of each of the three texts, collected from the same informant at different times. In other words, the informant reproduced the same stories she had told twelve years earlier. All texts are narratives, traditional folklore tales in Khanty.

The speaker is Olesya Yosifovna Sopochina (born on June 16th, 1988, in Surgut). Her parents keep reindeer, and the family and kin live in the upstream area of Tromagan, on the bank of one of the tributaries of the River Tromagan, wǒki răp jăwan 'the river of the fox hill'. Every member of the family is well acquainted with the traditions and customs of the Khantys and has good command of the singing and relating of folklore tales. Sopochina's grandfather, Ivan Stepanovich Sopochin (1910-1993), was the most famous shaman in this area. ${ }^{2}$

The first interview was carried out in the family's autumn residence in the village on July 25th, 1996. Márta Csepregi recorded Olesya Yosifovna Sopochina's narrations when she was eight years old. At that time she told five tales to Csepregi. On the following day, these tales were written down and translated with the help of her father, Yosif Ivanovich Sopochin. At that time, she was not yet at school, because parents living a traditional life send their children to school when they are able to live independently of their parents. The nearest school at that time was in the village of Russkinskiya, which is about 100 kilometres away from her home. At school, children live in a dormitory and return home only at holiday times.

Even though the family only spoke Khanty at home, Olesya had learnt some Russian expressions from her cousins when they spent summers at the home of their grandfather and uncle (= Olesya's father). Her cousins live in a town and can only speak Russian. She went to school in Russkinskiya 1996-2006 and completed an eleven-year schooling in ten years.

In the autumn of 2006, Sopochina started her studies in the Yugra University in Khanty-Mansiysk. Her major subject is the Khanty and Russian languages. She entered the university without an entrance examination, since she had won a prize in a literature competition. The tale she wrote was later published in the newspaper Khanty Yasang ('The Khanty language'; 26/2007, p. 4).

\footnotetext{
1 This study was carried out with the financial support of the Finno-Ugrian Society and the Finnish Graduate School in Language Studies/Langnet (Sachiko Sosa) and the project OTKA K 68061 of the Hungarian Scientific Research Fund (Márta Csepregi). The authors express their gratitude for this support.

2 For more information on Ivan Stepanovich Sopochin, see Csepregi (forthcoming).
} 
During the academic year of 2007-2008, she studied Hungarian and Hungarology at the Balassi Institute in Budapest. She worked with Sachiko Sosa in the spring of 2008 as the latter's informant in a study of Surgut Khanty syntax and pragmatics. At that time, the authors of this report came up with the idea of asking her to reproduce those tales she had told to Csepregi in her childhood. The second recording was made on April 9th, 2008. Sopochina did not listen to her earlier recordings and was only reminded of the themes of the tales.

Sopochina is nowadays totally bilingual. Since the death of her grandparents (in 1993 and 2001), who did not speak Russian, every member of the family is bilingual, even though they speak mostly Khanty at home. Code switching between Khanty and Russian is therefore quite common even within a sentence. According to Sopochina, even the dogs of the family understand orders in Russian and they speak exclusively in Khanty only to the reindeer. At school and university, Sopochina speaks Russian almost without exception, as there is only one student from the Surgut Khanty area in her year in Khanty-Mansiysk. Due to internal phonetic, morphological and syntactic differences within the Khanty languages, speakers from different areas have to speak Russian even with other Khantys. As an informant, Sopochina made a deliberate attempt to avoid using Russian words in the recordings. Later she was annoyed when she listened to herself on the tapes and noticed that some Russian words had, nevertheless, been left in the recordings.

\section{Folkloristic and ethnological background to the tales}

We wanted to hear three out of the five tales, which had been recorded in 1996, since these three are outstanding from the point of view of Khanty folklore or ethnology (the other two were somewhat mixed tales of a child). Folkloristic samples belong to the most important material in anthropological linguistics, because, in addition to a speaker's gender, social class, nationality, etc., cultural dimensions influence the linguistic form. In fact, a 'genre' can be said to consist of historically transmitted and relatively stable frameworks for orienting the production of discourse. Even though it is strongly connected with the social practice of language production and understanding in a community, it can still be flexible and open to manipulation by performers. (Foley 1997: 359)

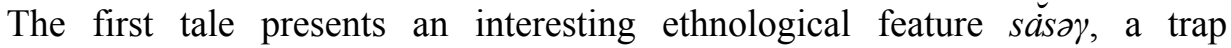
('Balkenschlagfalle'; KT 880b, DEWOS 1380), which U.T. Sirelius described and photographed (Sirelius 1983: 42-43, 86-87) and which is still in use. Sirelius also mentioned that the trap is set on a sandy bank of a river, where capercaillies are

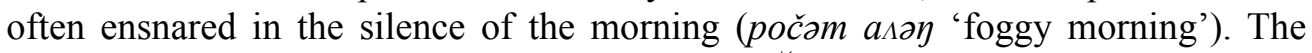

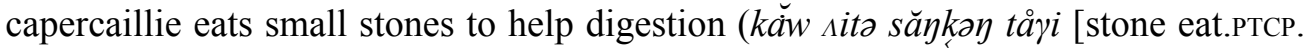
PRS sandy place] 'sandy place of stone eating'). The capercaillie typically appears as an extremely stupid animal in the folklore tales of Khanty. In this story, too, it dies because of its own stupidity.

The second tale is an instruction to respect fire. According to a Khanty belief, one of the Fire-goddess's daughters lives in every flaming fire. Thus Khantys should 
not touch the fire with sharp objects in order that the Fire goddess not be harmed. The Selkups have a similar kind of myth (Shestalov 1991a: 36), too. There are some variations of this tale. In both versions, 1996 and 2008, of our samples, a wife (imi 'a married woman') attacks the fire with an axe, although conversely, in one of the variations in Vakh Khanty (Lukina 1990: 180), not a wife, but a husband attacks the fire with an axe, and this makes the fire die out. The fire is reignited when the pair offers their child, asleep in the cradle, to the Goddess.

The third tale, which explains the origin of the cuckoo, is also well known in the whole area of Khanty. A variation in Agan Khanty has been transcribed in Russian (Lukina 1990: 75-76), and another in Kazym Khanty in Russian (Shestalov 1991b: 14) and Khanty (Solovar 1996: 23). According to Kulemzin (2006: 103), the cuckoo is not considered a real bird, but an image of a supernatural being in Khanty. According to Mansi mythology, the god of the sky, Numi Torem, changes the woman into a cuckoo: when the god settled in the land of humans, the legs of his horse sank into the mud. The god asked the woman for help in raising his horse from the mud, but she didn't want to help, because she was sewing. The god then became angry with her, and as punishment she was changed into a cuckoo. In the Mansi version, her daughter and son, who were orphaned, die (Munkácsi 1896: 321-322).

In addition of the revealing the origin of the cuckoo, the tale explains the reason why moss is red. The tale ends aetiologically, disclosing that moss turned red from the blood of the feet of the children who had run after their mother barefoot. Kulemzin (2006: 103) is familiar with a legend in which the mother's feet, and not the children's, bled while escaping from the children, tinting with red a certain willow species, not moss. Such aetiological explanations do not appear in Lukina's or Solovar's variations.

\section{Linguistic analysis of the tales}

This sample of tales offers an example, which shows how the same speaker can produce a different narration, both linguistically and propositionally, at different moments. At the level of pragmatics, the strategy and rhetoric of the speaker, for example, had developed for twelve years, although the story itself changed only a little. Even though the length of the entire text sample is almost the same (the length varying according to the tale, however), generally speaking, the speaker used more repetition of words (and not rhetorical parallels) and repairs in 1996 than in $2008 .^{3}$

In 1996, the informant used the word iki for 'man' and lük iki for 'capercaillie man' (1996/A), whereas in 2008 she used different expressions, kăntək ko 'a man' and luk iki (2008/A), to avoid confusion. In addition, the narrator's strategies aimed at manipulating listeners are manifest in the discourse, for example in the information flow through the choice of noun phrases. The choice of noun phrase is one of the most important elements in the information flow: formal shift of same referent,

3 Such specific features in discourse were deleted from our samples in order to avoid any lack of clarity. 
for example, from a full NP to a pronoun, from one noun to another, etc., shows the speaker's strategy. These strategies may include a wish by the speaker to emphasise or focus the didactics of the story or to show a shift in point of view. By using such strategies, new nuances are added to the referent, the character in the story, and as a result the new NP can, in discourse, be regarded as a type of new information. ${ }^{4}$ A proficient speaker can succeed in manipulating his/her listeners by enlarging the narrative story's field and world. (E.g. Martin 2003.)

In general, Sopochina described the situation and characters more precisely in 2008 than in 1996. Another example is evident from samples C. In 1996, the informant had chosen only the woman as a topic at the beginning of the story, but in 2008 she chose both the woman and the man as a beginning topic (see sample 1996/C below). This could be explained within the framework of traditional Khanty rhetoric, as the informant has mastered the traditional Khanty folklore tale formula better after 12 years. Traditionally, Khanty tales often begin, for example, with imiyzn-ikiyzn 'woman and man'. Each genre has its own framings in its rhetoric. This text genre typically has, for example, framings such as 'once upon a time' as an opening phrase, parallelisms or lexical shifts in poetic function, consisting of historically transmitted and relatively stable frameworks for orienting the production of discourse. Such framing enhances mutual understanding between the listener and the speaker (Foley 1997: 359-370). Furthermore, Khanty has similar features in its genres, for example, folkloristic discourse. These framings are manifest in parallelisms and certain beginnings, such as $\partial j$

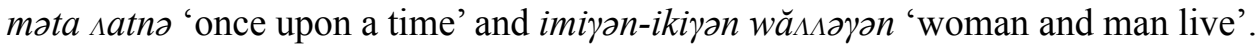

At the level of morphology, it is to be observed that the case marker of the loca-

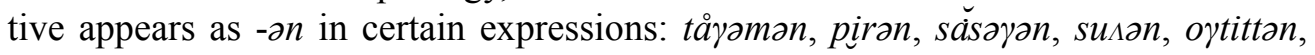
ıatวn. In Surgut Khanty, the locative is marked basically as -nə, which originated in the locative of Proto-Uralic, but also -an is one of the variations of locative case markers nowadays. This variation probably has a phonetic explanation.

At the syntax level, too, some changes are visible. The word order in Khanty is SOV and this verb finality is a fairly rigid rule in all Khanty dialects (e.g. Csepregi 1998). This basic word order has been maintained well in both old and new tales. Only two sentences in 1996 and six in 2008 are not verb final. In other words, the texts of 2008 have more non-verb ending sentences. Most of such sentences end in adverbials. For example:

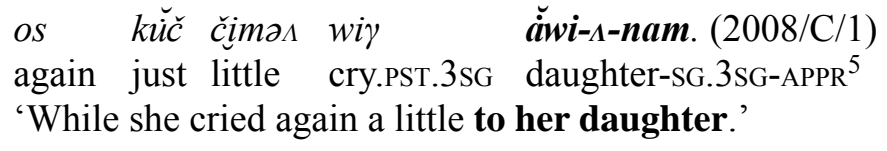

In 1996, to one of these an adverbial was added at the end as additional information.

\footnotetext{
4 The definition of new/given information varies depending on the scholar. Martin's "new information" would be considered as given information in other theories.

5 The less common abbreviations used in the glosses stand for approximative (APPR), comitative-instrumental (COMINST) and instructive-final (INSTFIN) cases.
} 

lük

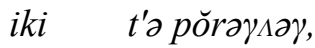
ротцау
krorap

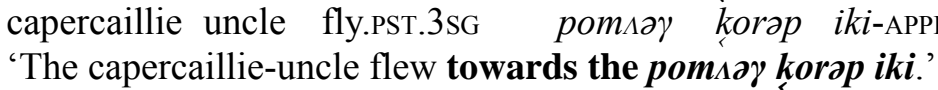
capercaillie uncle fly.PST.3SG pomıəy korəp iki-APPR
'The capercaillie-uncle flew towards the pomsəy korəp iki.'

In Khanty, afterthought constructions are represented by an element added after the completion of the sentence to clarify another word or the content of the whole sentence (Nikolaeva 1999: 57). The borderlines of the completion of the sentence and the additional information are separated by a pause. In the 2008 rendering, two non-verb ending sentences represent afterthought constructions of this kind. For example:

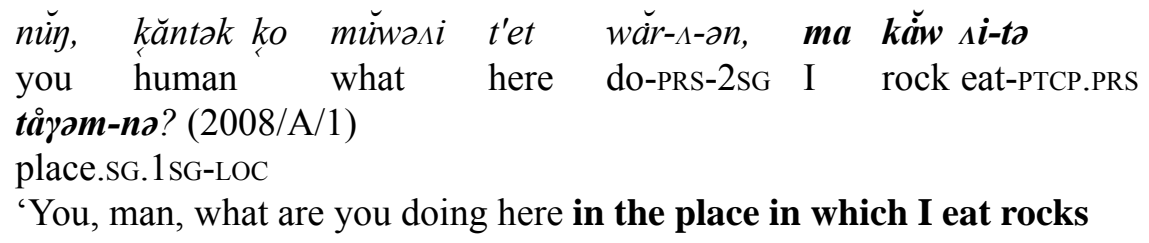

In 1996 another sentence violating verb finality is an imperative. In this sentence, too, the intonation unit ends at the verb, 'give', and then a pause follows before the object noun phrase. This can also be considered additional information.

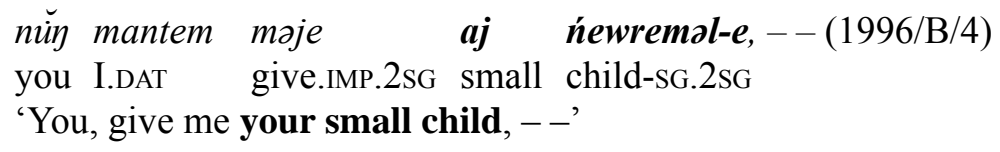

Thus, these parallel texts make it possible to examine what an adult remembers from her childhood and how language has changed. The difference of performance between 1996 and 2008 matches that of the narratives of an 8-year-old with that of a 20-yearold. There was child-like enthusiasm in the young girl's performance, while the adult speaks about what she remembers.

\section{The samples of Surgut Khanty 1996 and 2008}

Our sample narratives are shown below. The letters A-C correspond to each other in both the 1996 and 2008 samples. In translation, the authors wish to comment on two topics:

1. Tense. The tense of the original Surgut Khanty text and that of the English translation do not correspond to each other entirely. Because Surgut Khanty has only two tenses (present and past), the English tense system was used in the translations.

2. Conjunctions. Some of the translation sentences begin with a conjunction such as 'and', even though in general a sentence does not begin with such a conjunction in English. Here our purpose was to record the conjunction literally in spite of the difference of rhetoric in these two languages. We aimed at reproducing the manner of narration of in the original text clearly and faithfully. 


\section{I. The samples from 1996}

\section{6/A iki săsay wăr - A man made a trap}

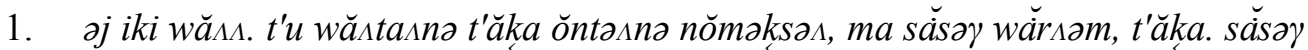

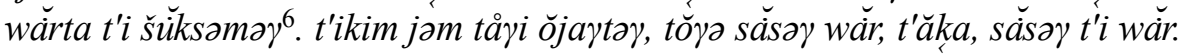

A man lives. In so doing he thinks to himself, "I shall make a trap". He starts to make the trap. This is a good place, he makes the trap there, he secures the trap.

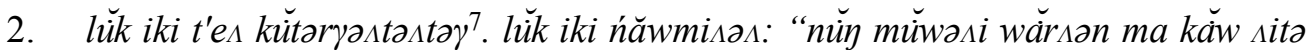

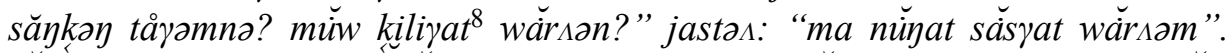

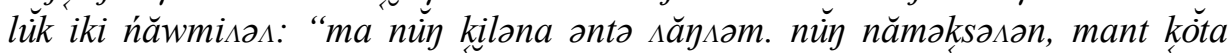

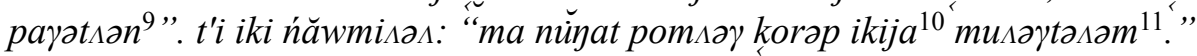

6 šŭksamay 'to start working on a difficult job'. There is no mention of this meaning and the initial consonant $\check{c}$ - in dictionaries (DEWOS 264, 266; Ter. 46), but the shift between $\check{c}$ and $\check{s}$ is a common phenomenon in the Tromagan dialect.

7 kütaryastastay is the onomatopoetic word for a capercaillie's movement, 'step on the sand in mixing with his (two) wings'. The word is found neither in KT, DEWOS nor in Ter. A similar word is found in only Mogutayev's dictionary of Vasyugan, but this is the variation of back vowel: қутарқ̧алтанта 'трепыхать' 'writhe, wriggle' (Mog. 116).

8 kili '1. wood-stack/pile; 2. privy, latrine'. A word in exactly same form and meaning is not found in dictionaries (cf. KT 299a, 300b; DEWOS 483, 486; Ter. 161).

$$
\begin{aligned}
& \text { köt-a payat-ıən } \\
& \text { hand-LAT make(.it).fall-PRS.2SG }
\end{aligned}
$$

'catch'; literally "make it fall into the hand". This word structure is not mentioned in dictionaries.

10 pomıวy korəp iki The translation could be 'uncle of grassless channel'. Cf. poməy kor 'channel with grass in low ridge' (Tremyugan), KT 329b; cf. also Ter. 173. This is one of the names of wåjay årtta iki 'god who divides animals', but nowadays speakers do not understand it fully themselves, either. Thus, it is not a coincidence that this expression does not appear in the 2008 variant. Cf. 2008/A/1 wajay årtta iki.

11 тиләуталәm The stem of the verb is mus- 'pray, sacrifice'. The derivative mus tionaries (KT 555b, DEWOS 922, Ter. 268). The meanings 'cry, call/invite with crying, ask, give, endow' illustrate that this verb describes all communication which takes place between human beings and sprits during the sacrificial activities. It means that human beings offer sacrificial animals to the god-after all the humans will in the end acquire the game. The meaning, which appears in section 1996/A/1 'intend/mean/offer sg for sy/sg', is mentioned only in the dictionary of Mogutayev (152). In the dictionary, government of the verb is different from that in the paragraph 1996/A/4.

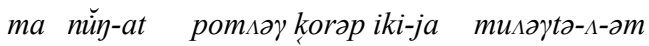

$$
\begin{aligned}
& \text { I you-ACC p.k.i.-LAT mean-PRS-1SG } \\
& \text { 'I offer you to the pomıəy korap iki.' }
\end{aligned}
$$

In paragraph 1996/A/4, the meaning of the verb тиләүtว- is different: the god supplies humans with game.

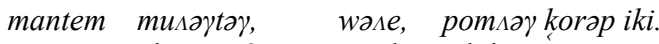

$$
\begin{aligned}
& \text { I.DAT give.PST.3SG surely p.k.i. } \\
& \text { 'Surely, the pomıay korap iki sent you to me.' }
\end{aligned}
$$


A capercaillie-uncle toddles towards it (= in sweeping the sand). The capercaillieuncle says: "What are you doing in my rock-eating sandy place? What kind of wood-stack are you making?" He says: "I make a trap for you." The capercaillieuncle says: "I won't enter your wood-stack/branch-heap. Do you think you can catch me (you drop it into the hand)." The man says: "I shall offer you to the

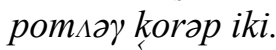

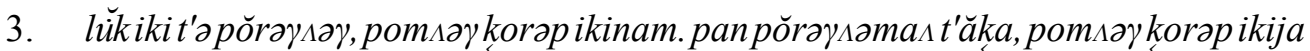

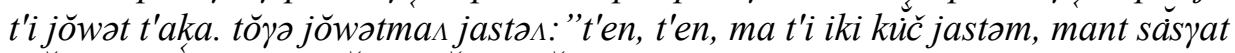

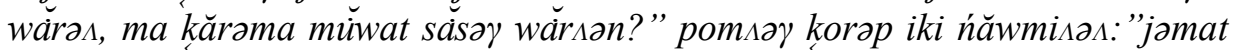

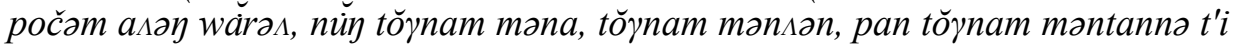

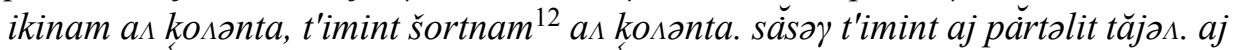

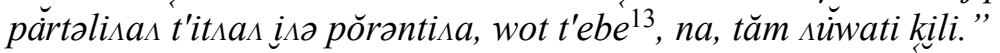

The capercaillie-uncle flew towards the pomıəy korəp iki. Then, after he had

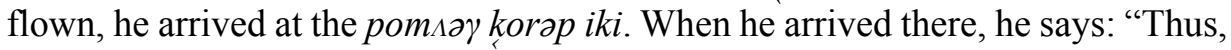
thus, I said to the man in vain, he makes a trap for me, why are you (= man) making a trap in my territory?" The pomıəy korəp iki says: "[tomorrow] will be a very foggy morning, go there, when you go there, don't mind the man, don't mind such an evil. The trap has a wooden slat. Tread on the slat, thus, this is for you, well, [it was sent] to him, a pile of wood."

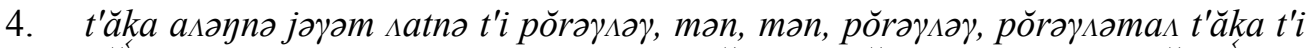

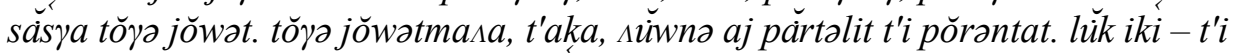

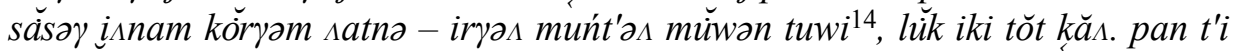

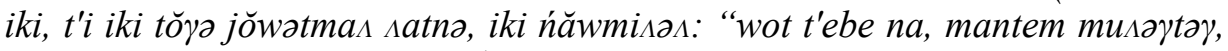
wase, pomıวy korap iki." wsjo. ${ }^{15}$

\footnotetext{
12 šortnam $\leftarrow$ Russian чёpm 'evil' childhood. 14

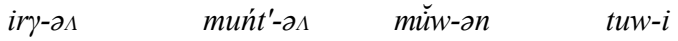

$$
\begin{aligned}
& \text { song-SG.3sG story-SG.3sG something-LOC take-PST.PASS.3sG } \\
& \text { 'His song, his story was taken away by something.' }
\end{aligned}
$$

13 wot t'ebe $\leftarrow$ Russian вот тебе 'take that! (this is for you)'. When listening to the 12-year-old recording, Sopochina was surprised and wondered where she had learnt this Russian expression in her

This passive structure refers to death. In Ob-Ugrian folklore it is quite common for a song and tale to appear together as a parallel expression and this is often a symbol of life (Radomski 1985). The alternative variation expresses death in a different metaphor:

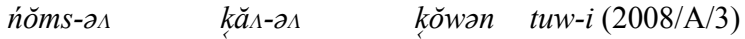

$$
\begin{aligned}
& \text { thought-SG.3SG death-SG.3sG far take-PST.PASs.3sG } \\
& \text { 'His thought and death are taken away.' }
\end{aligned}
$$

15 wsjo $\leftarrow$ Russian $8 c \ddot{e}$ 'That's all.' 
When the morning came, the capercaillie flew off, left, went, flew away, and after he had flown off, he arrived at the rap while in flight. When he arrived there, well, the trap fell down through him. The capercaillie-uncle-when the trap fell down - what had taken his song, his story was taken away by something, the capercaille-uncle died there. The man, the man says when he gets there: "This is

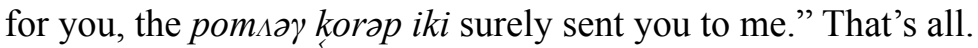

1996/B ť̈wat imi - The fire goddess

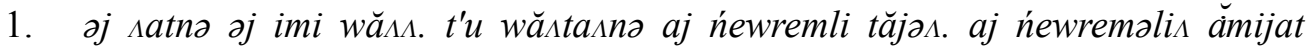

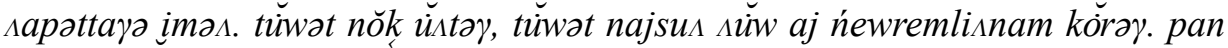

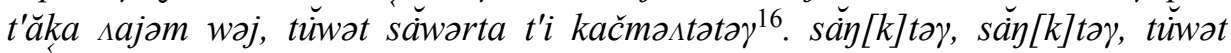

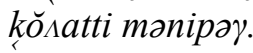

Once upon a time, there was a (married) woman. While living so, she has a child. She sits down to breast-feed her small child. When she kindles the fire, a spark falls onto her child. Then there she grips an axe, chops at the fire unceasingly. She beats, beats, [then] the fire vanishes (goes somewhere suddenly).

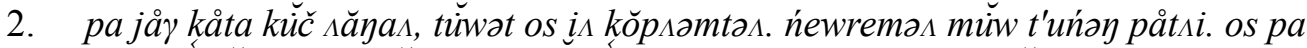

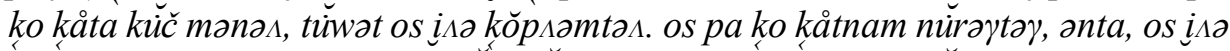

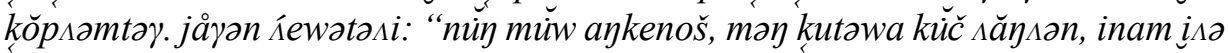
kорралиаt”.

When she steps into other's house the fire also dies there. Her child certainly freezes. Again she goes to another's home, the fire dies, similarly. She runs to another's home, no, there also [the fire] dies. The people scold her: "How evil it is, when you step into our house, all the fires die."

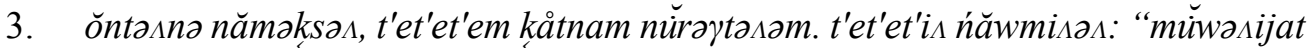

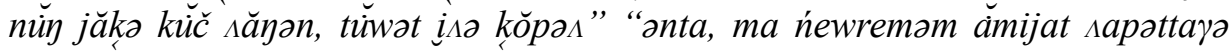

16
săwarta t'i kačmastatoy
chop.INF PRT vomit.PST.3SG
'She chopped at the fire unceasingly.'

In the Terëshkin dictionary (96), the word kačmasta means ' 1 . vomit something; 2 . bend the stream of the river', but according to Sopochina, this verb means unceasingly doing, in other words, this is a converbstructure, in which the verb kačmasta has lost its original meanings, and adds the function of Aktionsart of the verb sáwarta as 'unceasingly'. This structure is interesting, since such a structure has not been documented in any previous Khanty texts. It is also interesting that first this appears with the verb in the infinitive säworta 'cut, chop', then (1996/B/3) both main verb and converb are in the passive of the past tense third person singular: săyki, săyki kačmasti 'stroked without a break'. 


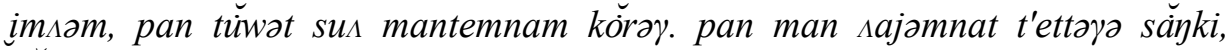

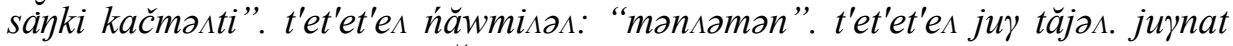

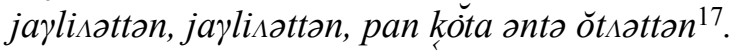

She thinks to herself, "I shall run to my grandfather's house." Her grandfather says: "Well, well, when you step inside (= my house), the will fire die." "No, I sit down to breast-feed my child, and the spark of fire falls on her. Then I struck with the axe, struck without a break." Her grandfather says: "We (two) shall go (= Let's (two) go!)." Her grandfather has a wooden poker. The two poke/stir, stir [the ashes] with the wooden poker, but they don't find anything (= they don't find a living coal).

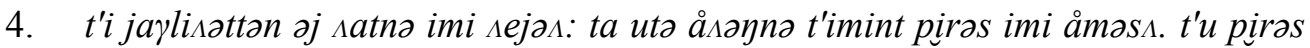

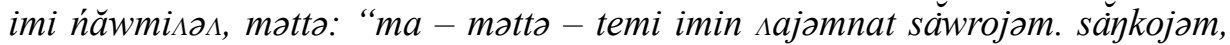

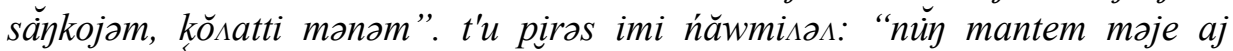

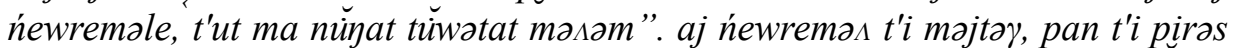

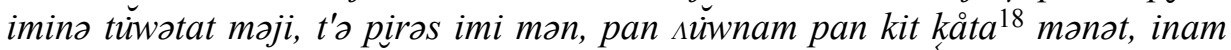
tüwtayka jayat. wsjo.

When they (= two) stir, the woman once saw: an old woman sits down at the upper end (of the house). The old woman says — she says: "I — she says - I was cut with an axe by that woman. I was beaten, beaten, and (she) vanished." The old woman says: "You, give me your small child, then I shall give you the fire." She gave her the small child, and the fire was given by the old woman, [then] the old woman left, and she herself...and the two of them went to their own houses, everything changed to fire (= everywhere the fire in flames). The end.

17

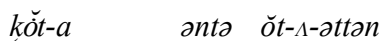
hand-LAT NEG get-PRS-3DU
'They don't get anything.'

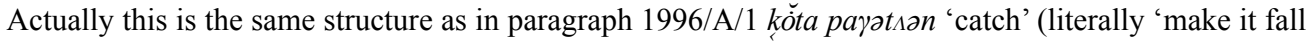
into the hand'), but in spite of the verb stem, the word $\check{t} t$ 'thing, matter, object' is used. The word can take suffixes of verb and it is possible to alter the meanings of any verb, which is clear from context. This functions in a same way as the Hungarian word izé 'something', which is its etymological counterpart. 18

kit kåt-a

two house-LAT

'in two different houses' 


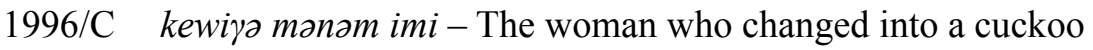

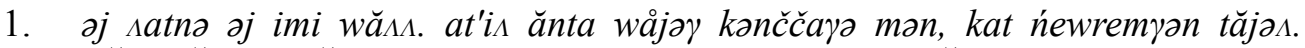

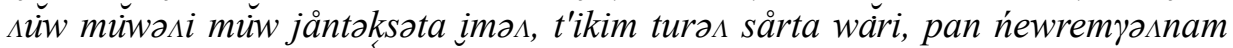

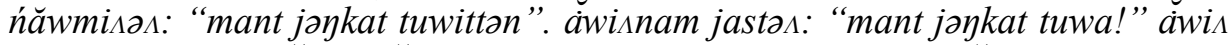

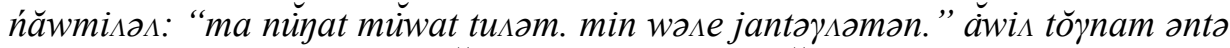

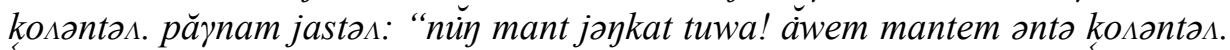
mant jəykat tuwa!” jəykat pan antə tuwattən.

There was once a (married) woman. Maybe their father went hunting, she has two children. She sat down to sew something, and when she becomes thirsty she says to her two children: "Bring me water." She says to her daughter: "Bring me water!" Her daughter says: "Why should I carry it to you? Since we two are playing." The daughter doesn't listen to this. She says to her son: "You, bring me water! My daughter doesn't listen to me. Bring me water!" Even now they two haven't brought any water.

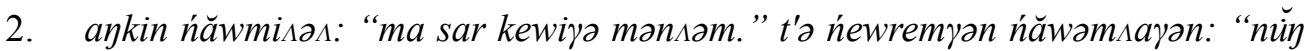

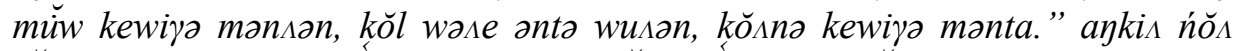

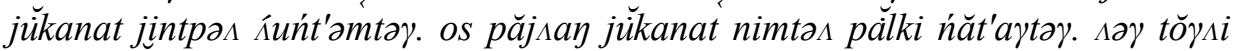

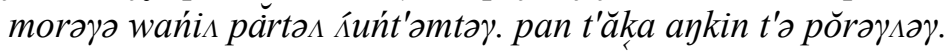

Their mother says: "Go ahead, I shall change into a cuckoo." The two children say to her: "How can you change into a cuckoo since you don't know how to change into a cuckoo?" Their mother stings the sewing needles in the place of her nose. For wings, she tore a pin cushion into two. She carved the cutting board for a tailfeather. The mother of the two [children] flew away.

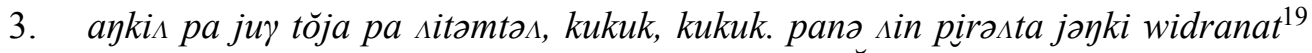

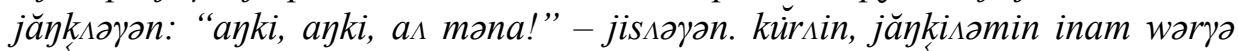

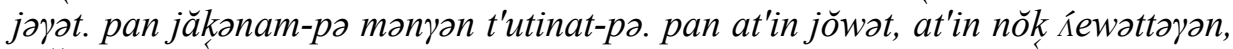
müw anta íewattayan. pan t'i taram, wsjo.

Their mother lands from a tree onto another, [then she] cuckoos, cuckoos. They two (= two children) went after her with a water bucket: "Mother, mother, don't go away!"- they cry. Going barefoot, there was pure blood. They went home with it. Their father came and scolded them or didn't scold them. Thus, the finish, the end.

19

jayk-i $\quad$ widra-nat

water-ABL pail-COMINS

'with a water bucket'; $\leftarrow$ Russ. ведро 'bucket' (Cf. 2008/C/3 kewəA 'container'.) 


\subsection{The samples from 2008}

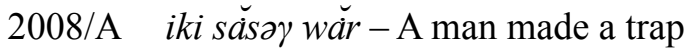

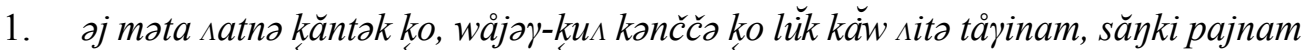

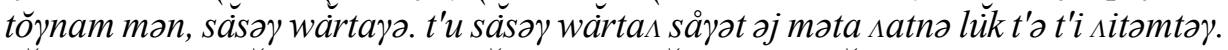

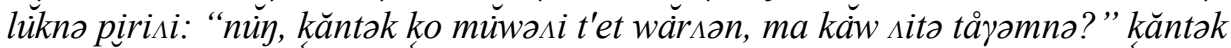

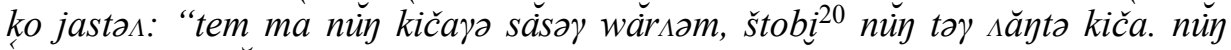

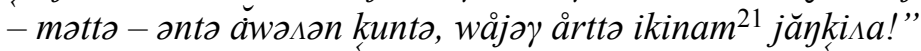

Once upon a time, a man, a hunting and fishing man went to the place where capercaillies eat rock, to a sandy hill, in order to make a trap. While making the trap, a capercaillie settled down. The capercaillie asks: "You, human, what are you doing here in my rock eating place?" The man says: "Well you see, I'm making a trap for you, so that you will step into." "You,- - he says - if you don't believe it, go to the game-dividing god!"

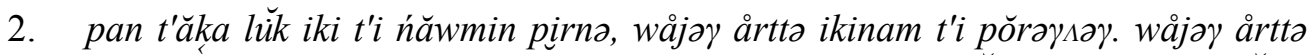

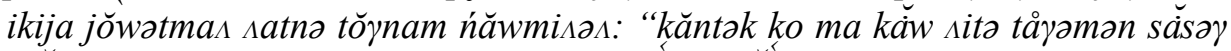

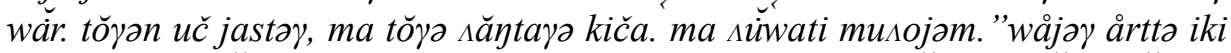

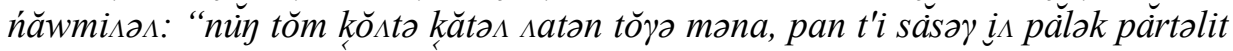

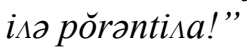

After they two had talked, the capercaillie flew off to the game-dividing god. When he came to the game-dividing god, he said to the god: "A human made a trap in my rock eating place. He says I shall step into it. I was ordered by him." The game-dividing god says: "Then you, go there tomorrow, and tread down the small boards under the trap."

20 štobi $\leftarrow$ Russ. чтобы 'so that' conjunction of finale sentence. In the first instance (2008/A/1), this would not be necessary: the sentence is understandable without this conjunction since the participle structure has already a postposition, kiča 'for, because of' which refers to the final adverbial. In the second instance $(2008 / \mathrm{B} / 1)$, the structure is copied directly from the Russian: чmoбbl + preterite verb:

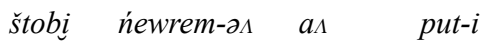

so.that child-SG.3SG NEG.IMP freeze-PST.PASS.3SG

'...so that her child wouldn't freeze.'

21

$\begin{array}{lll}\text { wåjar } & \text { årto } & i k i \\ \text { animal } & \text { divide.PTCP.PRS } & \text { old.man }\end{array}$

'the old man, who devides games/animals'

According to a Surgut Khanty belief, the god of the sky (toram at'i) had seven sons and one of them is this man who can be consulted on hunting luck (Kerezsi 1997: 36). 


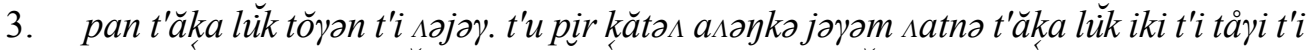

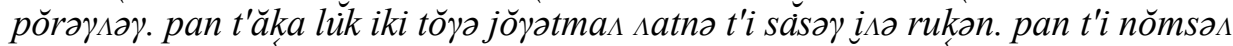

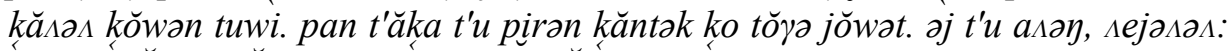

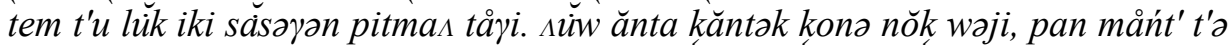
toram.

And then the capercaillie did this. So, when it was changed the next morning, the capercaillie-uncle flew to that spot. When the capercaillie-uncle arrived there, the trap spung. [and] His thoughts and death are taken away. [and] After that, the man came there. That morning, he can see: it looks as if the capercaillie-uncle had fallen into the trap. The man pulled him out, and that's where the tale ends!

2008/B tüwat imi - The fire goddess

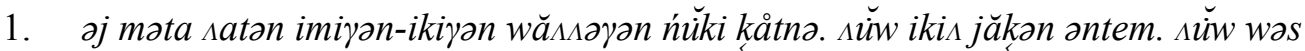

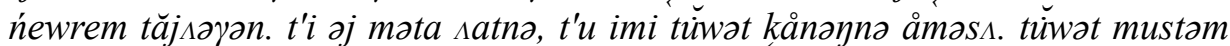

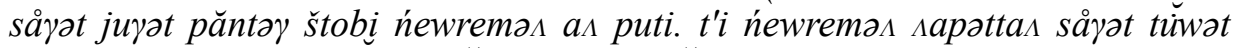

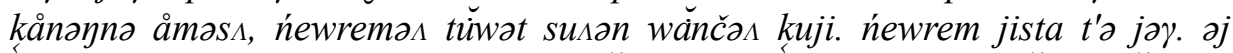

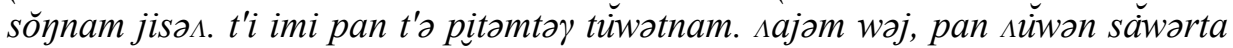

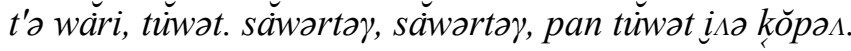

Once upon a time a woman/wife and a man/husband lived in a hut. Her husband isn't at home. They have a child. Once, the wife sits down near the flame. She burdens the flame with (fire)wood, so that her child wouldn't freeze. When she feeds the child, she sits down near the flame, and a spark flies in the child's face. The child begins to cry. Suddenly, s/he cries more and more. The woman gets angry at the flame. She brings an axe and begins to chop the flame. Chops and chops, the flame dies out.

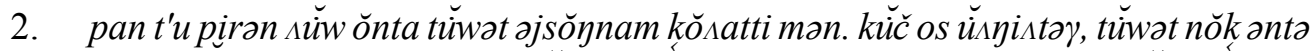

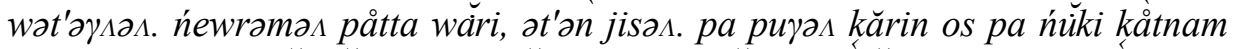

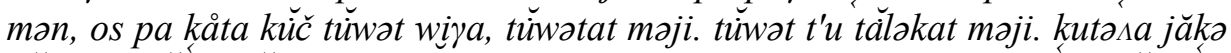

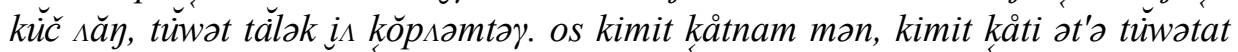

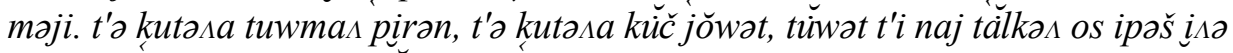

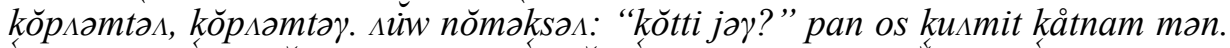

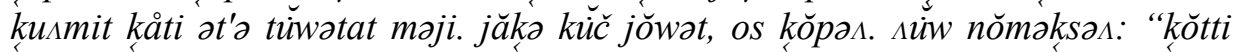
jay?"

After that, surely the flame died out. When she ignites it, it is not in flames. Her child begins to freeze and cries. In the village (square), she went to another hut and asked for light, the light was given. Living coal was given to her. After she brought [it] to her hut, when she arrived home, the living coal died out. She went to the second house again; light was given to her in the second house. When she arrived home, the living coal dies out again. She thinks: "What has hap- 
pened?" Then she goes to the third house again. Light was given (to her) in the third house. When she got home, the light died out again. She thinks: "What has happened?"

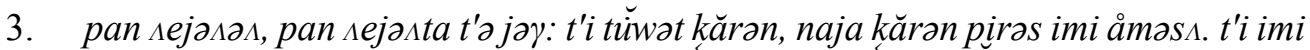

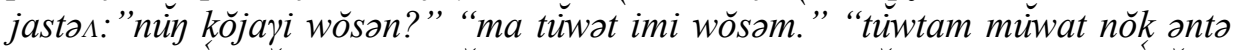

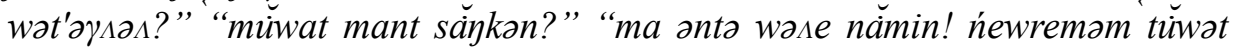

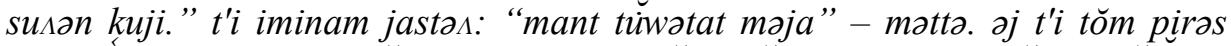

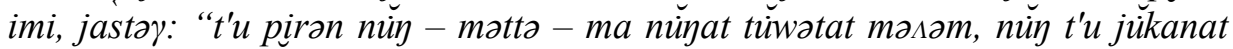

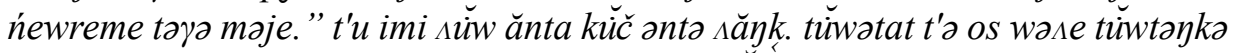

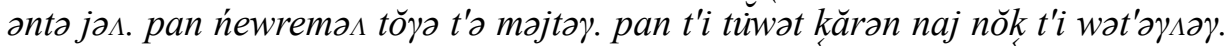
pan t'i imi ńewrem katasmin mulam jŏta nŏknam t'a man. $t^{\prime} i$.

And she can see: in the fireplace, an old woman is sitting down. The woman says: "Who are you?" "I am the goddess of fire." "Why doesn't my light catch fire?" "Why did you chop me?" "I didn't do it on purpose! A spark flew at my child." The woman said to her: "Give me the fire"- - she said.—Then, the old woman said: "Then, you,_- she said-I am giving you the fire. You, give your child to me instead of that." The woman, however, didn't want it. It was not caught in the fire. (= The fire doesn't become fire.) [and] She gave her child to it. Then the fireplace catches fire. And the woman ( $\mathrm{imi}$ ) goes up, together with the smoke, holding the child. That's it!

2008/C kewiy manəm imi - The woman who changed into a cuckoo

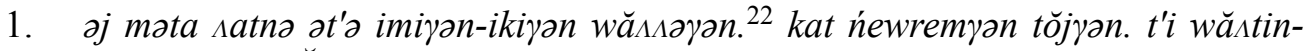

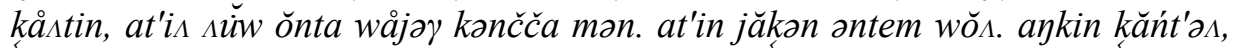

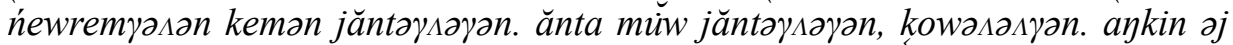

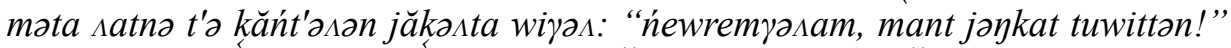

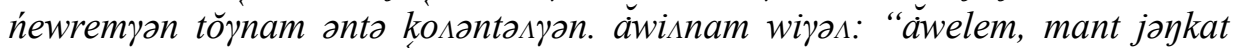

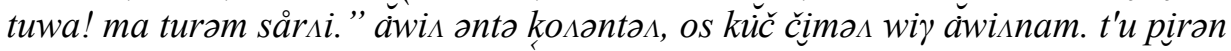

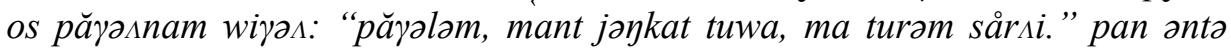

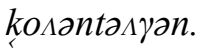

Once upon a time there was a woman and a man, too. They had two children. Living and sleeping like this, the father went hunting. Their father wasn't at home. Their mother is sick, the two children play outside. They might play or run

22

\begin{tabular}{|c|c|c|c|c|c|c|}
\hline oj & $\begin{array}{l}\text { mota } \\
\text { some }\end{array}$ & $\begin{array}{l}\text { sat-na } \\
\text { time-LOC }\end{array}$ & $\begin{array}{l}\partial t^{\prime} \partial \\
\text { PRT }\end{array}$ & $\begin{array}{l}\text { imi-yən } \\
\text { woman-DU }\end{array}$ & $\begin{array}{l}i k i-\gamma \partial n \\
\text { man-DU }\end{array}$ & $\begin{array}{l}\text { wă } \Lambda-\Lambda-\partial \gamma \partial n . \\
\text { be/live-PRS-3DU }\end{array}$ \\
\hline
\end{tabular}

The word $\partial t^{\prime}$ ' 'again' refers to the previous tale. This functions pragmatically to make cohesion between these two tales. 
around. Once their mother cries from the sickbed: "My (two) children, bring me water!" The children don't listen to her. She cries to her daughter: "My daughter, bring me water! I am thirsty. (My throat is dry.)" Her daughter doesn't listen while she cries a little again to her daughter. After that she cries to her son, too: "My son, bring water to me, I am thirsty." [and] they don't listen to this.

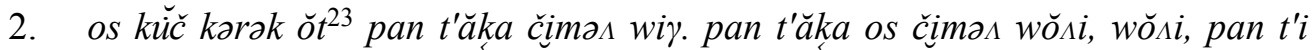

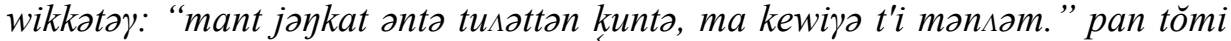

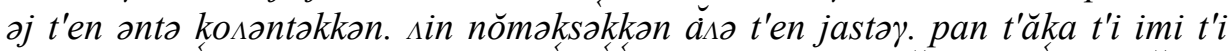

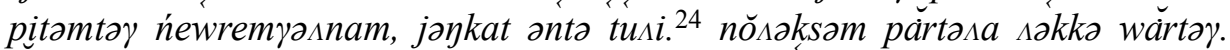

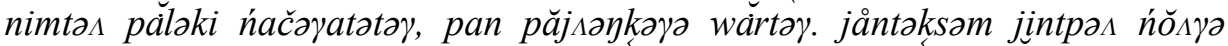

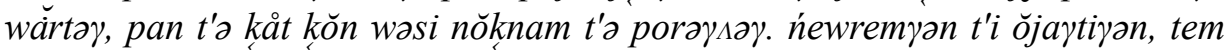

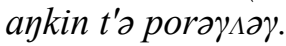

Soon again the poor (= mother) cried a little. Then again she was and was short, and she shouted: "If you don't bring (me) water, I shall change into a cuckoo!" [and] No-one listened to this. They two think that she is just talking. Then the woman gets angry with her two children, [because] they won't bring water to her. She makes a tail from a leather-treating board (small piece of wood). She tears a pin cushion in two and makes wings. She makes a beak from a sewing pin. Then she flies out of a smoke outlet. Her children notice that she had flown away.

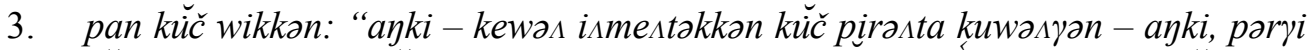

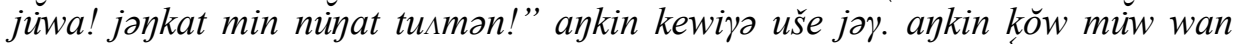

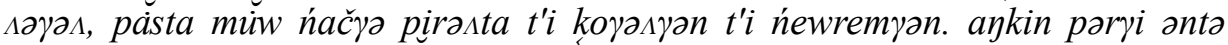

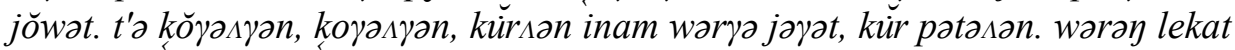

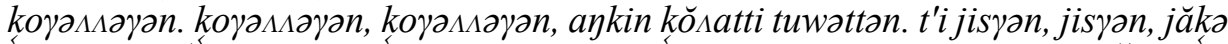

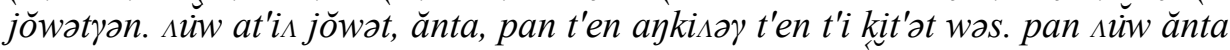

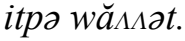

And they (two children) cried: "Mother-those two took a vessel, when they two ran after [their mother] — the mother, come back! We shall bring you water! "Their mother had already changed into a cuckoo. Their mother flew far, another

23 karək ŏt: literally 'ungodly someone', actually pitying expression 'poor thing' $\leftarrow$ Russ. zpex 'crime, $\sin$.

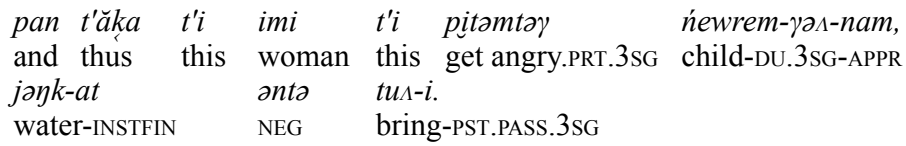

'And thus this woman got angry at her two children [because] the water wasn't brought.'

Although this sentence has no conjunction, it is understandable. 
near, [and] one child ran fast, the other slowly. Their mother didn't come back. Thus, they ran and ran, their feet/soles were all in blood. They ran in the bloody footmarks. They ran, ran, where their mother was being carried. Thus then they cried, cried, and went home. Maybe their father arrived, and they stayed without mother, I think. And surely, they lived on.

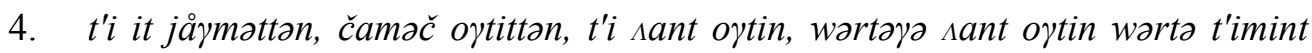

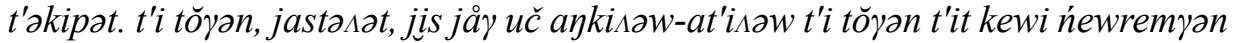

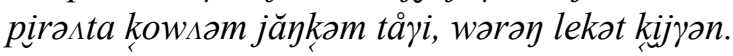

So now, in the pine forests, on the surface of the peat moss, on the surface of the lichen, on the surface of the red lichen, there are such red spots. So, it is said, the ancestors, our mother, our father, that the bloody footprints remained in the place where the cuckoo's children went.

\section{References}

Csepregi, Márta 1998: Szurguti osztják chrestomathia. Studia uralo-altaica supplementa 6. Szeged: József Attila Tudományegyetem.

Csepregi, Márta (forthcoming): The very highly connected nodes in the Ob-Ugrian networks. - Jussi Ylikoski (ed.), The Quasquicentennial of the Finno-Ugrian Society. Mémoires de la Société Finno-Ougrienne 258. Helsinki: Société Finno-Ougrienne.

DEWOS = Steinitz, Wolfgang 1967-1993: Dialektologisches und etymologisches Wörterbuch der ostjakischen Sprache. Berlin: Akademie Verlag.

Foley, William A 1997: Anthropological linguistics. An Introduction. Oxford: Blackwell.

Kerezsi, Ágnes 1997: Life and Beliefs of the Ostyaks of the Surgut Region. - Katalin Lázár (ed.), Studies on Surgut Ostyak Culture. Budapest: Museum of Ethnography.

KT $=$ Karjalainen, K. F. \& Toivonen, Y. H. 1948: Ostjakisches Wörterbuch. Lexica Societatis Fenno-Ugricae X. I-II. Helsinki: Société Finno-Ougrienne.

Kulemzin, Vladislav. M 2006: Kukkuuk. - Vladislav M. Kulemzin, Nadezhda V. Lukina, Timofei A. Moldanov \& Tat'yana A. Moldanova (eds.), Khanty mythology. Encyclopaedia of Uralic Mythologies 2. Budapest: Akadémiai Kiadó \& Helsinki: Finnish Literature Society.

Lukina = Лукина, Н. В. 1990: Mифы, предания, сказки хантов и манси. Москва: Наука.

Martin, Laura 2003: Narrator virtuosity and the strategic exploitation of PAS in Mocho Repetition and constructed speech in Mocho narrative. - John W. Du Bois, Lorraine E. Kumpf \& William J. Asyby (eds.), Preferred Argument Structure. Grammar as architecture for function. Amsterdam - Philadelphia: John Benjamins Publishing Company. 411-435.

Mog. = Могутаев, М. К. 1996: Хантыйско-русский словарь (васюганский диалект). Томск: Томский госпедуниверситет.

Munkácsi, Bernát 1896: Életképek. Vogul népköltési gyüjtemény IV. Budapest: Magyar Tudományos Akadémia.

Nikolaeva, Irina 1999: Ostyak. Languages of the World/Materials 305. München: Lincom Europa. 
Radomski, Rosemarie 1985: Zur Interdependenz von Leben und Erzählen. - Ursula Pieper \& Gerhard Stickel (eds.), Studia Linguistica Diachronica et Synchronica. Werner Winter Sexagenario Anno MCMLXXXIII. Berlin: Mouton de Gruyter.

Shestalov = Шесталов, Юван 1991а: Сказки народов Севера. Ленинград - ХантыМансийск: Белый Журавль.

Shestalov = Шесталов, Юван 1991b: Хантыйские сказки. Ленинград - Ханты-Мансийск: Белый Журавль.

Solovar = Соловар В. Н. 1996: Моньшат па путрат. Нижневартовск: Нижневартовский педагогический институт.

Sirelius, U. T. 1983: Reise zu de Ostjaken. Übersetzt und herausgegeben von Ingrid Schellbach. Suomalais-ugrilaisen Seuran kansatieteellisiä julkaisuja XI. Travaux ethnographiques de la Société Finno-Ougrienne. Helsinki: Société Finno-Ougrienne.

Ter. = Терёшкин, Н. И. 1981: Словарь восточнохантыйских диалектов. Ленинград: Наука.

Márta Csepregi <csepregim@ludens.elte.hu>

Department of Finno-Ugric Studies

Eötvös Loránd University

P.O. Box 107

HU-1364 Budapest

Sachiko Sosa < sachiko.toguchi@helsinki.fi>

Department of Finno-Ugrian Studies

P.O. Box 25

FI-00014 University of Helsinki 